AUTHOR CORRECTION OPEN

\title{
Author Correction: Coevolutionary search for optimal materials in the space of all possible compounds
}

Zahed Allahyari (iD) and Artem R. Oganov (D)

npj Computational Materials (2020)6:105; https://doi.org/10.1038/s41524-020-00381-9

Correction to: npj Computational Materials https://doi.org/10.1038/ s41524-020-0322-9 published online 14 May 2020

The original version of this Article contained errors in the third and fourth sentences of the legend to Table 1, which incorrectly read 'The hardness was computed using the Chen-Niu model ${ }^{23}$, the fracture toughness-using the Niu-Niu-Oganov model ${ }^{27}$. Refs. $a^{40}, b^{41}, c^{52}, d^{53}, e^{58}, f^{59}, g^{60}, h^{61}, i^{62}, j^{63}, k^{64}, m^{66}, n^{67}, p^{68}, q^{69}$. The correct version revises all references and states 'The hardness was computed using the Chen-Niu model ${ }^{72}$, the fracture toughnessusing the Niu-Niu-Oganov model ${ }^{74}$. Refs. $\mathrm{a}^{29}, \mathrm{~b}^{30}, \mathrm{c}^{43}, \mathrm{~d}^{44}, \mathrm{e}^{49}, \mathrm{f}^{50}$, $\mathrm{g}^{51}, \mathrm{~h}^{52}, \mathrm{i}^{53}, \mathrm{j}^{55}, \mathrm{k}^{56}, \mathrm{~m}^{58}, \mathrm{n}^{57}, \mathrm{p}^{54}, \mathrm{q}^{59}$.' This has been corrected in both the PDF and HTML versions of the Article.

\begin{abstract}
Open Access This article is licensed under a Creative Commons Attribution 4.0 International License, which permits use, sharing, adaptation, distribution and reproduction in any medium or format, as long as you give appropriate credit to the original author(s) and the source, provide a link to the Creative Commons license, and indicate if changes were made. The images or other third party material in this article are included in the article's Creative Commons license, unless indicated otherwise in a credit line to the material. If material is not included in the article's Creative Commons license and your intended use is not permitted by statutory regulation or exceeds the permitted use, you will need to obtain permission directly from the copyright holder. To view a copy of this license, visit http://creativecommons. org/licenses/by/4.0/.
\end{abstract}

(c) The Author(s) 2020 